\title{
Toponym's Transmigration in Pringsewu to Historical Empathy Student of Class X Senior High Scholl 1 Pringsewu
}

\author{
Aprilia Triaristina \\ History Education \\ Lampung University \\ Lampung, Indonesia \\ aprilia@fkip.unila.ac.id
}

\author{
Yustina Sri Ekwandari \\ History Education \\ Lampung University \\ Lampung, Indonesia \\ yustina.sriekwandari@fkip.unila.ac.id
}

\author{
Sumargono \\ History Education \\ Lampung University \\ Lampung, Indonesia \\ sumargono.1988@fkip.unila.ac.id
}

Abstract-The reality in history learning at a high school located in Pringsewu shows the fact that students are not yet skilled at showing the empathy aspect of history comprehensively. Historical empathy (historical empathy) of students towards their historical environment is still limited to inventory and documentation. They are used to visiting historical sites in Pringsewu. However, they have not been able to interpret the historical values found in the transmigration villages in the Pringsewu area. Many students do not know the history of the naming of Pringsewu and the historical villages in the Pringsewu area, even the history of the village they live in. The purpose of this study is focused on the objective of integrating toponymy philosophical values in local history learning as education about the history of transmigration at SMA N 1 Pringsewu. This study used data triangulation, namely by means of interviews, observations, and document analysis. Based on the results of preliminary data analysis, it is found that history learning has not been able to spur the growth of social systems, reaction systems, instructional impacts; and a support system that can arouse students' interest and historical empathy to understand and feel the situation of events and actions of historical agents, learning based on the uniqueness of toponymy in Pringsewu Regency has not been developed with the characteristics of local historical material. The results of the data analysis after learning about the history of Toponymy in transmigration villages in Pringsewu Regency, and being included in the history lesson, class $X$ students at SMA Negeri 1 Pringsewu, were very enthusiastic about this material, and increased historical empathy. because so far, history learning only refers to general material, it does not mention local history in the local area.

Keywords - Toponimi, Historical Empathy, History Learning.

\section{INTRODUCTION}

History learning that is studied should not only be associated with a series of events that occurred in the past. But actually in interpreting history learning students can also be directed to be able to see and analyze real events that occurred in their closest community, by linking problems social events that occur in the closest environment of students into history learning. This is in line with what was expressed by Agus Mulyana \& Restu Gunawan (2007) students' emotional closeness to the surrounding environment is a valuable historical learning provided [1]. The formatter will need to create these components, incorporating the applicable criteria that follow. resource for the learning process in the classroom.

The curriculum in Indonesia in recent years has undergone several changes that have made teachers and students a little confused, but in the past 5 years it seems to have been patented by the implementation of the latest edition of the 2013 curriculum which actually provides opportunities for teachers and schools who become facilitators to be able to develop more comprehensive learning materials. interesting for students, namely by utilizing natural and social phenomena that exist in the nearest community environment by exploring. cultural and historical aspects that are local in nature to become learning materials in the classroom.

One of the themes that can be developed as learning local history is a theme related to "toponymy" which examines the origins of naming regions. The study of local toponyms is everything that discusses the closest, interesting and detailed local history topics or in Rosihan Anwar's term it is called petite histoire. The origins in naming 
places/regions will certainly not be separated from the discovery of distinctive and unique things which will eventually become an identity for the place/region itself. Tracking the toponym of a place/region has a role in tracing the historical background of the activity or initial conditions when the place/region was formed [2].

It is very unfortunate, if someone lives in a place and becomes a permanent resident but does not know anything about the history of naming the place he lives in. Even though every place name, be it a village name or a sub-district name, has its own unique and interesting history because they have community characteristics based on their historical background [3]. Therefore, if it continues, it is not impossible that the younger generation will present an "ignorant" situation in the nature of the name of the region, maybe even in their own name.

According to Encep Supriatna (2012), assessing that facing the phenomenon of this global era, there are several opinions regarding the position of historical education, which of course greatly influences the development of historical materials and curriculum today [4]. But in reality the learning that occurs in the field is still only focused on historical materials that are universal in nature with the hope that students can understand their position and can implement them in real life. However, if only universal history learning materials are studied, the problem will arise what about the student's own identity in real life if he does not understand his own history. Whereas history learning should be responsive to the changing times, without distorting local culture and history which will foster a sense of historical empathy in students and of course strengthen their identity and love for the homeland.

Problems and challenges that must be faced are the competence of teachers in an effort to develop local-based teaching competencies that collide with national history patent materials and specializations that have been determined by the government. History teachers are required to be able to complete a lot of material with limited teaching time which of course makes it difficult for history teachers to implement the development of learning materials based on local excellence modified with innovative learning models.

The extent of this study of toponymy, so that researchers focus on the research focus on the topic of toponymy in naming transmigration villages in Pringsewu. Emphasizing research on toponymy in the Pringsewu area, this is influenced by the historical origins of Pringsewu which is the location for the first transmigration placement itself which is indeed interesting to study because almost the entire Pringsewu area starting from the village government structure, language, to village naming uses elements of the Javanese language, but the younger generation there does not really understand the history of the origins of how the process of village names can come to use languages outside the Lampung area, it is ironic that if it is allowed to continue it will fade one of the cultural heritage of naming the village.

\section{LITERATURE REVIEW}

Learning is a learning and teaching process that is planned and designed to provide knowledge provided by educators to students in the learning process. Learning will be successful if teachers and students can work together. According to Asep Mahfudz (2012), teachers play an active role as facilitators who help facilitate students in learning and students can develop an understanding of knowledge and skills so that students are able to learn independently or designed, implemented, and evaluated systematically so that students can achieve learning objectives effectively and efficiently [5].

History learning is a combination of learning and teaching activities in which learning about past events is closely related to the present [6]. Meanwhile, the context of nation building Historically, teaching history does not solely function to provide historical knowledge as a collection of historical fact information but also aims to awaken students or raise awareness of their history [7].

A group of people who first stop by and occupy a new area will usually give a name to make it easy to identify, which is often created that is still closely related to the language and culture of the origin of the first people who occupy the new area. According to Alwi (2005), mentioning names is a form of language in human life and is the result of human perception [8]. In the process of giving this name, of course there is a series of stories that can become the history of the origin of the name of the area which in scientific studies is included in the field of toponymy. According to Jacub Rais (2008) toponym, in English "toponym" literally means the name of a place on earth ("topos" is "place" or "surface" such as "topography" is a description of the surface or places on earth , and the "nym" of "onyma" is "name"), and in English are sometimes called "geographical names" or "place names" [9].

According to Titiek Suliyati (2011), tracking a place/region has a role in tracing the historical background and activities or initial conditions when the place/region was formed [2]. Sudaryat (2009) suggests that there are three aspects in naming a place, namely embodiment aspects, social aspects, and cultural aspects [10]. The first is the embodiment aspect, which is related to things that are physical in 
nature, meaning that toponyms containing embodiment aspects are usually related to the state of the natural environment such as land surface, waters, and the natural environment such as plants and animals. The second is the social aspect, namely the toponymy that is created related to the relationship between human social relations in community groups, such as time, social and economic activities to the profession. The third aspect is the cultural aspect related to the belief system of the community, also related to history, oral literature. and others.

Regarding the world of education, the coverage of toponymy material is something new and quite good because it contains educational and cultural values. This is supported the toponymy of local names in Canada shows the perspective of names that use local languages as a means of communicating knowledge of nature, native languages and oral history [11]. Based on some of the explanations of the experts above, it can be underlined that toponymy is a branch of onomastics that examines the process, history and origins in naming a geographical area which includes planting villages, sub-districts, districts, countries, roads, rivers and others that are often in these names relate to the three aspects of toponymy (society, embodiment and culture).

Introducing discussion material on local toponyms as a source of student learning in history subjects is the right thing because it includes all of the traditional values, culture and history of the name which is certainly an important and useful part in helping preserve the local cultural heritage. Historical empathy or historical empathy is a process in which a person is involved logically/cognitively and affectively/emotionally towards historical events or figures to better understand comprehensively how people in the past thought, feel and act [12]. The further opinion expressed by Risma Oktavianti and Aisiah (2019) historical empathy is an entry point for exploring and internalizing the values of the exemplary character of the characters being studied, thus it is hoped that history teachers will no longer only focus on the completeness of subject matter, but will prioritize character building students through historical empathy learning models and learning methods [12].

Based on the explanations of several experts above, it can be underlined that the concept of historical empathy is included in the scope of history learning skills. Experts have the view that teaching empathy means guiding students to be able to explain and understand what happened in the past. Historical Empathy has a role as a dual-domain construct in which the thoughts and actions of historical actors are linked to their affective situations.

\section{RESEARCH METHODS}

This research is a qualitative research, "Qualitative method as a research procedure that produces descriptive data in the form of written or spoken words from people and observable behavior on the status of a group of people or humans or an object or a cultural group". Qualitative methods can be interpreted as problem solving procedures investigated by describing or describing the state or object of research (a person, institution, community and others) at the present time based on the facts that appear or as they are.

In this study, the social reality that was studied was the local wisdom of the people of Pringsewu Regency in knowing the history of Transmigration in the toponymous village. This local wisdom is reflected in the history of the toponymy of transmigration of villages in Pringsewu district. Local intelligence in preserving the history of the transmigration village needs to be integrated into student learning at school, one of which is through learning local history at SMA N 1 Pringsewu.

This research was conducted at SMA $\mathrm{N} 1$ Pringsewu. The selection of the research location was carried out purposively, namely choosing deliberately with the intention of getting a location that was considered relevant to the research objectives. Data analysis technique is a technique in examining and analyzing data so that it can present it as reliable data. According to Miles (2014) data analysis is carried out through several stages which include [13]:

- Data collection is the process of collecting research information through data collection based on predetermined data collection techniques

- Data condensation refers to the process of selecting, focusing, simplifying, abstracting and transforming data that can be in field notes and transcripts in research

- Data Presentation as a structured collection of information that provides the possibility of drawing conclusions and taking action which includes: various types of matrices, graphs, networks and charts.

Conclusion (verification) Drawing conclusions is part of an activity from a complete configuration. Conclusions are also verified during the research. This verification may be as brief as a rethink that passes through the analyst's (researcher) mind as he writes, a review of field notes, or it may be very thorough and laborious with review and brainstorming among colleagues to develop intersubjective opportunities and efforts -extensive efforts to place a copy of a finding in another data set. 


\section{RESULT AND DiSCUSION}

\section{A. Historical Empathy}

Empathy is an element that is quite difficult to define perfectly, completely and touches all its aspects [14]. But in general, empathy is widely discussed on various topics of discussion about psychology [15]. Psychology itself is a discipline that discusses humans and internal aspects of humans such as thoughts and feelings and external aspects such as human relationships. Empathy has an important role in human relationships because it allows sharing experiences, needs and connecting feelings in social life [16]. In a special term regarding the psychology of empathy, this understanding makes a person interact with other humans in order to understand and understand feelings and behavior according to differences in time and context [17].

Having a feeling of empathy that is not limited by time, gives birth to a new topic of empathy itself. Intersubjectivity resulted in the emergence of various combinations between disciplines that were initially different [18]. Likewise, empathy is synonymous with the context of the present or future time. Eventually empathy develops which leads to an understanding of the reasons behind people in the past acting. Based on this past empathy, it helps different disciplines to understand the traditions and customs that occur today [18].

Historical empathy or historical empathy until now there is still a debate about its definition Historians use the word empathy to fulfill past events and their relationship with the present [19]. In understanding the past itself, historical empathy itself according to historians is considered an inseparable value from history [20]. The use of empathy in history learning is because to understand the past from the perspective of other people or historical figures, a thorough understanding of the past life is needed before it is finally connected with today's conditions [21].

Based on the analysis of the initial needs data, history teachers in developing historical empathy so far have not been able to arouse the interest of students to study history more deeply. Weak efforts in utilizing the potential historical empathy of students. The teacher did not take the initiative to give about the history of the toponymy of the area to be taught to students. Historical Empathy of students towards the historical environment is limited to intervention and documentation. Meanwhile, according to the teacher, the students' historical empathy ability towards their local history is considered normal.

Learning in schools, which strongly supports history learning by utilizing the potential of toponymy history in Pringsewu, is inversely proportional to the professionalism of teachers. The application of historical empathy to history learning can help high school students in building themselves to position themselves to feel and understand about events and the history of the toponymy of the Pringsewu area. That from the results of the initial needs of students carried out by researchers, data obtained that in general the historical empathy level of students is still at a very low level. This means that students have not been able to understand and know about the history of the toponymy of the Pringsewu area in history lesson.

Historical empathy implies that the history of toponymy is very important for students to know. In order to foster historical empathy, students need to apply critical thinking skills, such as the ability to analyze meanings, perspectives, traces and interpretations of the past. In addition, the skills that need to be developed to form historical empathy are understanding the historical context in accordance with historical facts. This kind of understanding is then used to form historical imagination and to form sensitivity to various points of view on historical event.

\section{B. Pringsewu Toponimy}

The toponym in the Pringsewu area of naming a place can be viewed from several aspects, including physical aspects or aspects of embodiment and sociocultural aspects. This aspect indicates that a place is given a name. Physical aspects are divided into several groups, namely hydrological aspects, geomorphological aspects, and biological-ecological aspects. Hydrological naming is the naming of an area by looking at the waters. In Pringsewu Regency, areas that have a hydrological aspect are marked by the names "way" which is Lampung language for water and "banyu" which is Javanese for water. In addition to the hydrological aspect, the naming of the villages in Pringswu is also related to the geomorphological aspect, namely aspects related to the condition of the earth's surface or landscape. Biological-ecological aspects also influence the names in Pringsewu. Names related to the names of plants, fauna, and related to one of the elements of nature.

The physical aspect greatly influences the naming of the village in Pringsewu, as well as the sociocultural aspect. Socio-cultural aspects are aspects related to social conditions, perspectives, social interactions, social activities and their places and equipment. The names of villages that consist of this element have two possibilities. First, these villages are Javanese-populated First, these villages are Javanese-populated villages.

The majority of the toponyms of the Pringsewu area are dominated by names containing Javanese elements, although there are some areas that also use other regional elements. This shows that the new place is in accordance with the area of origin. 
Therefore, it is fitting for the younger generation to really know the history of regional naming (toponymy), especially among high school students Because this toponymy inherited by our predecessors is used as part of identity formation.

\section{Historical Empathy Student}

Historical empathy skills for students need to be built in various ways, one of which is by increasing their understanding of historical events. This can be done by enriching knowledge through history books with various perspectives. An understanding of historical diversity in accordance with the interpretation of historians is a way that can be done in order to increase historical empathy.

Through this description, it can be concluded that high school students in Pringsewu Regency generally have the cognitive ability of empathy. Students have an understanding of what happened, the emotions felt by the characters and the reasons why the characters behaved in historical events. Students do not continue these feelings with the ability to respond to the same feeling. There are students who try to respond to a feeling in a historical event by writing down their feelings about the historical event. However, most students are only limited to knowing without then giving feedback on these feelings. This is because, most of the students' feelings are always rationalized. The rationalization carried out by students creates a neutral feeling in learning history so that objectivity in understanding historical events can be achieved.

Based on the types of empathy according to Zaluski, the empathy felt by high school students is included in the truncated empathy or imperfect empathy. The absence of the affective aspect of empathy in all students and the follow-up of these feelings causes students to only have one ability of empathy, namely cognitive empathy.

\section{CONCLUSION}

Based on the results of the study, the historical empathy ability of junior high school students is included in the category of cognitive empathy. Students have the ability to understand and understand historical events in the area where they live and can understand what historical figures consider in making decisions. Students are also able to give opinions about what happened in the past and assess how the history of the area acted. The complexity in understanding the selection of local customs and customs is also for students. So, students have fulfilled the cognitive element of empathy. However, with no further response to cognitive empathy found, students do not have the affective ability of empathy. So, according to Zaluski, this ability of empathy is the ability of the truncated empathy. The Truncated Empathy, which is limited to cognitive empathy, is owned by students because of their fairly good ability to see past events, not limited to one perspective. This is in accordance with the history lesson itself.

\section{REFERENCES}

[1] A. Mulyana \& R. Gunawan, Sejarah Lokal: Penulisan dan Pembelajaran Sejarah. Bandung: Salamina Press, 2007.

[2] T. Suliyati. Melacak Sejarah Pecinan Semarang Melalui Toponim.Artikel hasil penelitian. Jurusan Sejarah Fakultas Ilmu Budaya. Universitas Diponegoro, 2011.

[3] S. Priyadi. Sejarah Lokal Konsep, Metode dan Tantangan. Yogyakarta: Ombak. 2012.

[4] E. Supriatna. Transformasi Pembelajaran Sejarah Berbasis Religi dan Budaya untuk Menumbuhkan Karakter Siswa".Atikan, Vol 2(1). 2012. 21-44.

[5] A. Mahfudz. Cara Cerdas Mendidik yang Menyenangkan. Bandung: Rekatama Media. 2012.

[6] I. G. Widja. Dasar - Dasar Pengembangan Strategi Serta Metode Pengajaran Sejarah. Jakarta: Debdikbud. 1989.

[7] H. Susanto. Seputar Pembelajaran Sejarah. Yogyakarta: Aswaja Pressindo. 2014

[8] H. Alwi. Kamus Besar Bahasa Indonesia ke-3 Jakarta : Balai Pustaka. Depdiknas (2004). Kualitas Pendidikan. Jakarta: Depdiknas, 2005.

[9] J. Rais. Toponimi Indonesia. Jakarta: Pradnya Paramita, 2008.

[10] Y. Sudaryat. Toponimi Jawa Barat. Bandung: Dinas Pariwisata dan Kebudayaan Provinsi Jawa Barat, 2009.

[11] T. U. S. H. Wibowo, S. Sariyatun, and D. Djono. "Pengembangan Model Pembelajaran Sejarah Berbasis Keunikan Toponimi Kawasan Banten Lama Untuk Meningkatkan Historical Empathy Siswa Sma Negeri Di Kota Serang." HISTORIKA 21.1 (2018): 1-14.

[12] R. Oktaviani, and Aisiah, Kualitas Persiapan (Perencanaan) Metode Pembelajaran Bermain Peran Untuk Melatih Empati Sejarah Peserta Didik. Jurnal Halaqah, Vol 1 (3). 2019. 211.

[13] M. B. Miles, A. M.1 Huberman, and J. Saldana. Qualitative data analysis: A methods sourcebook. (2014).

[14] A. M. Dohrenwend. Defining empathy to better teach, measure, and understand its impact. Academic Medicine, 93(12), 2018. 1754-1756, https://doi.org/10.1097/ACM.0000000000002427.

[15] J. A. Hall, \& R. Schwartz, Empathy present and future. Journal of Social Psychology, 159(3), 2019. 225-243, https://doi.org/10.1080/00224545.2018.1477442.

[16] H. Riess. The science of empathy. Journal of Patient Experience, $\quad 4(2), \quad 2017 . \quad 74-77$, https://doi.org/10.1177/2374373517699267.

[17] T. D. Ellenwood Jr. Historical Empathy: judging the people of the past in a secondary social studies classroom. Learning to Teach, 6(1), 2017. 13

[18] K. B. Harris. Teacher strategies for developing historical empathy. 192, 2016. Retrieved from https:// s e a r c h-p r o q ues t-co m.d bg w.li s.c ur $\mathrm{t}$ in.e $\mathrm{d} \mathrm{u}$. a u/do $\mathrm{c} v$ ie $\mathrm{w} / 1853862278$ ? acco un $\mathrm{t}$ id $=10382$.

[19] K. Yilmaz. Historical empathy and its implications for classroom practices in schools. History Teacher, 40(3), 2007. 331-337, https://doi.org/10.2307/30036827

[20] D. L. Cunningham. Professional practice and perspectives in the teaching of historical empathy (Doctoral dissertation, University of Oxford), 2004.

M. Alsene. Exploring historical empathy in secondary education. Selected Honors Theses. 89, 2017. h t t ps://f ir es c h o l a r s.s eu .e d u/h o n or s/89. 